\title{
IMPLIKASI HUKUM PERUBAHAN BATASAN USIA PERKAWINAN KARENA PERMOHONAN DISPENSASI KAWIN TERHADAP PENINGKATAN ANGKA PERCERAIAN DI PENGADILAN AGAMA KABUPATEN PASURUAN
}

\author{
Ahmad Baihaqi Syamsuddin Saderi \\ Universitas Negeri Maulana Malik Ibrahim Malang \\ ervinsyams@gmail.com
}

\begin{abstract}
The phenomenon of young marriage is a "mode" that reoccur. In the past, marrying young was considered normal. Years changed, many marriages at an early age. The phenomenon is back again, if in the past parents wanted to marry young for various reasons, now many teenagers themselves aspire to marry young. In addition, some teenagers are an option to avoid committing sins, and in fact, many people also develop in emotional development, educational background, and so on. Youth and apply for a marriage dispensation at the religious court. Referring to the background explanation, various problems arise, including 1. What is the Impact of chapter 7 of Law Number 16 of 2019 on the Application for Marriage Dispensation at the Pasuruan Religious Court. 2. What is the Impact on the Increase in the Divorce Rate at the Pasuruan Religious Court. The research method applied is qualitative with the type of empirical juridical research (field research), and the approach used in this research is the conceptual approach and the statute approach. The results of this study are the renewal of chapter 7 of Law Number 16 of 2019 has a major impact on increasing the number of submissions for marriage dispensation at the Pasuruan Religious Court. Suppose the divorce rate in the Pasuruan Religious Court continues to grow from vulnerable in 20152021. In that case, The factors that suggest the number of divorces in the Pasuruan Court, leaving one, are domestic violence, parties and continuously, and the economy. Every year, couples file for divorce from teams who first apply for a marriage dispensation, except in 2021 (January-February); for couples who have filed for divorce, no one has submitted a request for marriage first.
\end{abstract}

Keywords: Divorce Rate, Marriage Dispensation, Law No. 16 chapter 7 of 2019

\section{Abstrak}

Fenomena kawin muda ini tampaknya merupakan "mode" yang terulang. Dahulu, kawin muda dianggap lumrah. Tahun berganti banyak yang menentang perkawinan diusia dini. Fenomena tersebut kembali lagi, kalau dulu orang tua ingin anaknya menikah muda dengan berbagai alasan malah kini banyak remaja sendiri yang bercita-cita kawin muda. Selain itu,beberapa remaja berpandangan menikah muda merupakan pilihan agar mereka terhindar dari melakukan perbuatan dosa, Pada kenyataannya, kematangan seseorang banyak juga bergantung pada perkembangan emosi, latar belakang pendidikan, sosial, dan sebagainya di masyarakat dari tahun ke tahun semakin banyak remaja yang ingin menikah muda dan mengajukan permohonan dispensasi kawin di Pengadilan agama. Mengacu pada paparan latar belakang tersebut, dengan 
demikian muncul bermacam problematika antara lain: 1. Bagaimana Dampak Pasal 7 Undang-Undang Nomor 16 Tahun 2019 Terhadap Permohonan Dispensasi Kawin Di Pengadilan Agama Pasuruan. 2. Bagaimana Dampak Terhadap Peningkatan Angka Perceraian Di Pengadilan Agama Pasuruan. Metode penelitian yang diterapkan yakni kualitatif dengan jenis penelitian yuridis empiris (field reseach) dan menggunakan Pendekatan penelitian yang digunakan dalam penelitian ini adalah pendekatan konseptual (conceptual approach) dan pendekatan perundang-undangan (statute approach). Hasil penelitian ini adalah Pembaharuan Pasal 7 Undang-Undang Nomor 16 Tahun 2019 terhadap Undang-Undang Nomor 1 Tahun 1974 mempunyai dampak besar bagi kenaikan jumlah pengajuan dispensasi kawin di Pengadilan Agama Pasuruan. mengemukakan jika tingkat perceraian di Pengadilan Agama Pasuruan terus meningkat dari rentan tahun 2015-2021 Faktor meningkatnya jumlah perceraian di Pengadilan Pasuruan, meninggalkan salah satu pihak, kekerasan dalam rumah tangga, perselisihan dan pertengkaran terus menerus, dan ekonomi. Di setiap tahunnya, pasangan yang mengajukan perceraian selalu ada dari pasangan yang dahulunya mengajukan dispensasi nikah, kecuali di tahun 2021 (Januari-Februari) untuk pasangan yang mengajukan perceraian belum adayang pasangan dahulunya mengajukan permohonan dispensasi nikah.

Kata Kunci: Batasan Usia, Perceraian, Dispensasi Kawin, Undang-undang No 16 Pasal 7 Tahun 2019

\section{PENDAHULUAN}

Dispensasi kawin adalah perizinan pernikahan kepada calon pengantin yang masih berada di bawah umur menurut oleh Undang-Undang Perkawinan. Pada dasarnya perkawinan oleh calon mempelai yang tidak mencukupi batas umur adalah dilarang, namun dapat diizinkan oleh Pengadilan Agama yang berbentuk surat dispensasi kawin, agar perkawinan tersebut bisa diproses di Kantor Urusan Agama. Dispensasi kawin yang telah dibatasi oleh umur 19 inilah yang hendak jadi suatu pemabahasan peneliti, serta pula terjadilah dispensasi kawin di Pengadilan Agama Pasuruan yang meningkat secara tajam juga menciptakan peningkatan angka perceraian, Dengan Undang-Undang Perkawinan Nomor 1 Tahun 1974 Pasal 7 Ayat (1) mengemukakan "Perkawinan hanya diizinkan jika pihak pria sudah mencapai umur 19 tahun dan wanita mencapai umur 16 tahun" yang setelah itu diganti menjadi Pasal 7 Undang-Undang Nomor 16 Tahun 2019 yang menyebutkan bahwa "Perkawinan hanya diizinkan apabila pria dan wanita sudah mencapai umur 19 tahun". Perubahan ini disebabkan banyaknya aspek serta akibat dari pernikahan dini. Dari data inilah peneliti memperhitungkan dengan pergantian suatu undang-undang tidak selamanya berdampak baik, tetapi dengan berkembangnya era, kita butuh memperbaikinya bukan menolaknya.

Kematangan fisik ataupun kejiwaan calon pengantin ialah salah satu asas yang dipakai regulasi perkawinan, sebab suatu perkawinan mempunyai 
misi yang sangat agung yakni mewujudkan keluarga yang tenteram dan memperoleh generasi yang shalih dan shalihah. Pernikahan yang terjadi sedangkan mempelai masih di bawah umur dicemaskan mempunyai potensi tinggi menciptakan generasi yang buruk, diakibatkan selain dari bibitnya yang belum dewasa namun pula sebab minimnya pengetahuan dari calon mempelai menimpa parenting, sehingga anak hendak berkembang serta tumbuh dengan pola asuh yang kurang optimal (Hakim, 2000). Perceraian memanglah merupakan suatu jalur keluar untuk suami istri yang memiliki kasus yang tidak bisa di selesaikan secara damai yang kalau perkawinan tersebut bila di pertahankan, maka akan mendatangkan modharat baik buat keduanya ataupun anak-anaknya, sehingga peceraian terpaksa wajib dilakukan. Pasal 7 ayat (1) Undang-undang Perkawinan Nomor 1 tahun 1974 jo pasal 15 ayat (1) Kompilasi Hukum Islam menyatakan bahwa perkawinan hanya diizinkan jika pria sudah mencapai umur 19 tahun dan pihak wanita sudah mencapai umur 16 tahun.4 Pernikahan untuk usia muda yang di bawah ketentuan peraturan perundang- undangan memang dibolehkan demi kemaslahatan. Secara metodologis, langkah penentuan usia kawin didasarkan kepada metode maslaha mursalah. Namun demikian, karena sifatnya yang ijtihad, yang kebenarannya relatif, ketentuan tersebut tidak bersifat kaku. Artinya, apabila karena sesuatu dan lain hal perkawinan dari mereka yang usianya dibawah 21 tahun atau sekurang- kurangnya 19 tahun untuk pria dan 16 tahun untuk wanita, undang-undang tetap memberi jalan keluar. Pasal 7 ayat (2) menegaskan bahwa dalam hal penyimpangan terhadap ayat (1) pasal ini dapat meminta dispensasi nikah. Dalam hal siapa yang akan memberikan pengecualian atau dispensasi, maka dikeluarkanlan Undang-undang Nomor 1 Tahun 1974 ayat (2) yakni dalam hal penyimpangan terhadap ayat (1) pasal ini dapat meminta dispensasi kepada Pengadilan atau pejabat lain yang ditunjuk oleh kedua orang tua pihak pria maupun pihak wanita. Dalam Undang-Undang Nomor 1 Tahun 1974 tentang Perkawinan, ditetapkan mampu fisik bagi perempuan berusia 16 tahun.

Menurut pengalaman perempuan yang kawin dalam usia yang sangat muda akan menghadapi resiko pada saat melahirkan. Kemampuan fisik bagi pria adalah berusia 19 tahun karena pada usia itu ia dianggap telah matang untuk berumah tangga. Pada usia itu besar kemungkinan mendapat kerja dan memperoleh penghasilan, karena suami dalam islam berkewajiban memberi nafkah dan tempat tonggal kepada istri dan anak keturunannya. Penomena kawin muda ini tampaknya merupakan "mode" yang terulang. Dahulu, kawin mudadianggap lumrah. Tahun berganti banyak yang menentang perkawinan diusia dini. Penomena tersebut kembali lagi, kalau dulu orang tua ingin anaknya menikah muda dengan berbagai alasan malah kini banyak remaja 
sendiri yang bercita-cita kawin muda. Selain itu, beberapa remaja berpandangan menikah muda merupakan pilihan agar mereka terhindar dari melakukan perbuatan dosa, seperti hubungan seks sebelum menikah misalnya. Pada kenyataannya, kematangan seseorang banyak juga bergantung pada perkembangan emosi, latar belakang pendidikan, sosial, dan sebagainya. Melihat Fenomena yang terjadi di masyarakat dari tahun ke tahun semakin banyak remaja yang ingin menikah muda dan mengajukan permohonan dispensasi kawin di Pengadilan agama.

\section{Metode}

Jenis penelitian yang diterapkan yakni yuridis empiris (field reseach) dimana mengkaji keberlakuan hukum di tengah masyarakat. Peneliti melaksanakan secara langsung penelitian di tempat penelitian yaitu Pengadilan Agama Pasuruan untuk mengetahui mengenai Dampak undangundang Pasal 7 Nomor 16 Tahun 2019 terhadap dispensasi kawin dan peningkatan angka peceraian di Pengadilan Agama Pasuruan. Penelitian Pendekatan penelitian yang digunakan dalam penelitian ini adalah pendekatan konseptual (conceptual approach) dan pendekatan perundangundangan (statute approach). Hal ini dikarenakan dengan pendekatan konseptual pertama kali peneliti harus beranjak dari pandangan-pandangan dan doktrin-doktrin yang berkembang didalam ilmu hukum dan agama. Dengan menggunakan pendekatan konseptual inilah, peneliti akan dituntut untuk merujuk pada prinsip-prinsip hukum yang dikemukakan oleh pandangan-pandangan ahli atau doktrin-doktrin yang ada.

Pada penelitian ini, penulis menggunakan pendekatan perundangundangan (statute approach). Pendekatan ini menelaah semua perundangundangan dan regulasi yang berkaitan dengan isu hukum yang sedang diteliti. Dalam penelitian ini, peneliti merujuk kepada pengkajian data Terkait dengan dampak undang-undang Pasal 7 Nomor 16 Tahun 2019 terhadap dispensasi kawin dan peningkatan angka perceraian di Pengadilan Agama Pasuruan. Peneliti disini memanfaatkan bermacam sumber data yang lazim dipakai dalam penelitian kualitatif, di antaranya ialah:

1. Sumber Data Primer

Sumber data yang bersifat autoritatif yang artinya mempunyai otoritas. ${ }^{4}$ Yang didapatkan secara langsung dari asalnya, diperhatikan serta didokumentasikan untuk pertama kalinya (Marzuki, 2000). Guna memilih siapa saja informan yang terlibat pada penelitian ini, peneliti menerapkan teknik Purposive sampling dimana teknik tersebut memilih sampel yang dilibatkan melalui penilaian tertentu. Penilaian sebagaimana dimaksud misalnya tingkat pengetahuan atau pemahaman informan, kedudukan 
informan pada lembaga yang terkait, yang diharapkan bisa mempermudah peneliti memperoleh data serta informasi yang dibutuhkan (Sugiyono, 2014). Mengacu pada penjabaran tersebut, dengan demikian yang dilibatkan pada penelitian antara lain:

a) Ketua Pengadilan Agama yaitu dengan H. Muslich, S.Ag, M.Hum, memiliki tugas pelaksanaan tugas-tugas ketua jika ketua berhalangan, membantu pembuatan program kerja jangka pendek serta jangka panjang, menentukan hari sidang, menentukan sita jaminan serta menginstruksikan juru sita pengganti, menyusun penetapan atau keputusan atas perkara yang diterima dan menyelesaikannya hingga akhir.

b) Ketua Panitera yaitu dengan Drs. Sholihan, M.Hum, memiliki fungsi penyelenggara administrasi perkara, serta mengatur tugas wakil panitra, membantu hakim dengan mengikuti dan mencatat jalannya persidangan, membuat daftar perkara-perkara, membuat Salinan putusan, dan bertanggung jawab atas pengurusan berkas perkara, putusan, dokumen, akta,buku lainnya.

c) Panitera Muda Hukum yaitu dengan Imammudin, S.H., M.H, mempunyai tugas melaksanakan pengumpulan, pengolahan dan penyajian data perkara, hubungan masyarakat, penetaan arsip perkara, serta pelaporan.

d) Pemohon, yaitu dengan M. Ghufron, orang yang memohon kepada lembaga pemerintah untuk upaya hukum.

e) Pemohon, yaitu dengan Siti Zaziroh, sebagai anak pemohon atau calon pengantin.

2. Sumber Data Sekunder

Sumber data yang memuat informasi penguat terkait dengan tema yang dikaji, misalnya skripsi, disertasi, ataupun jurnal-jurnal hukum (Marzuki, 2007). Sumber datasekunder ini menyajikan penjabaran terkait dengan sumber data primer, seperti rancangan undang-undang, hasil penelitian yang berupa isu-isu aktual mengenai bidang hukum tertentu, dan hasil karya dari kalangan hukum dalam bentuk buku maupun jurnal (Soekanto, 2006). Kegunaan sumber data sekunder ini adalah sebagai petunjuk bagi peneliti untuk berfikir dan menyusun argumentasi atau memberikan pendapat hukum (Marzuki, 2007).

Salah satu hal penting pada penelitian kualitatif yakni metode yag diterapkan peneliti dalam mendokumentasikan bermacam informasi yang ada di tempat penelitian (Masyuri dan Zainuddin, 2009). Disini peneliti menerapkan tiga macam teknik dalam mennghimpun data, yakni:

1) Dokumentasi 
Dokumentasi yakni sebuah cara yang dilakukan guna mendalami informasi historis. Lazimnya, data yang dalam bentuk dokumentasi tersebut antara lainberbentuk surat-surat, catatan, memo, buku, jurnal, dan sejenisnya (Kartono, 1990). Dalam arti luas, dokumentasi meliputi foto, gambar, monumen, artifak, harddisk, dan seterusnya (Bungin, 2013). Teknik ini diterapkan guna mendapatkan informasi terkait dengan profil Ketua Pengadilan Agama Pasuruan, beserta informasi terkait dengan dispensasi kawin dan peningkatan angka perceraian di Pengadilan Agama Pasuruan.

1) Observasi

Kegiatan observasi dalam penelitian yakni sebuah cara menghimpun informasi melalui pengamatan yang secara khusus menggunakan panca indera. Dalam penelitian ini, penyusun berusaha semaksimal mungkin supaya bisa mengikuti dan mencermati bagaimana dampak dispensasi kawin serta peningkatanangka perceraian tersebut.

2) Wawancara

Wawancara ialah tahapan mendapatkan informasi melalui aktivitas tanya jawab antara pewawancara dengan informan untuk menjawab permasalahan penelitian (Bungin, 2013. Informasi yang diperoleh dari wawancara merupakan data yang autentik karena diperoleh secara langsung dari narasumber yang bersangkutan. Sedangkan teknik wawancara yang digunakan yakni teknik wawancara sistematik, yakni wawancara yang pertanyaannya diatur sedemikian rupa secara sistematis dan menggunakan daftar pertanyaan tersebut sebagai haluan dalam menghimpun informasi dari narasumber.

Dalam hal ini peneliti akan mewancarai dengan H. Muslich, S.Ag, M.Hum sebagai Ketua Pengadilan Agama Dan Drs. Sholihan, M.Hum sebagai Ketua panitera.

a) Editing

Sesudah memperoleh bermacam informasi, peneliti kemudian mengolah informasi tersebut, dan tahapan pertama dalam pengolahan tersebut yakni tahap editing. Tahap ini merupakan tahap pemeriksaan terhadap kelengkapan, kejelasan, keterkaitan, serta relevansi data yang diperoleh bagi penelitian yang sedang dilaksanakan. Selain itu, akan dilakukan perbaikan bagi data yang masih meragukan, tidak jelas, dan sebagainya (Sunggono, 2016). Dalam proses penelitian ini penulis ingin mengetahui bagaimana dampak Undang-undang Nomor 16 Pasal 7 Tahun 2019 terhadap dispensasi kawin dan peningkatan angka perceraian di Pengadilan Agama Pasuruan.

b) Classifying

Setelah tahap pemeriksaan pertama atau editing selesai dilakukan, dilanjutkan dengan tahap kedua yakni classifying. Tahap memetakan data yang mana untuk keseuaian dengan penelitian, ini yakni tahap pemilahan antara berbagai macam data baik yang bersumber dari wawancara, dokumentasi, atau yang lainnya agar 
peneliti bisa mempermudah dalam mengolah data.

c) Verifying

Setelah data dipilah dalam tahap klasifikasi, maka selanjutnya yakni tahap pemeriksaan validitas data tersebut. Dalam hal ini peneliti akan meneliti secara langsung di Pengadilan Agama Kota Pasuruan.

d) Analyzing

Analyzing merupakan tahap pengkajian sertapenyederhanaan data yang didapatkan selama penelitian di Pengadilan Agama Pasuruan dengan tujuan memudahkan pembaca memahami tulisan ini.. Dengan ini peneliti akan menganalisis pengaruh dampak Undangundang Nomor 16 Pasal 7 Tahun 2019terhadap dispensasi kawin dan peningkatan angka perceraian di Pengadilan Agama Pasuruan.

e) Concluding

Conluding merupakan proses akhir dalam pengolahan data. Dalam tahap ini akan dicantumkan kesimpulan bermacam hasil analisis dampak Undang-Undang Nomor 16 Pasal 7 Tahun 2019 terhadap dispensasi kawin dan peningkatan angka perceraian di Pengadilan Agama Pasuruan yang telah dilaksanakan.

\section{HASIL PENELITIAN DAN PEMBAHASAN \\ Faktor Permohonan Dispensasi Kawin}

Bagi calon mempelai beragama Islam yang tidak memenuhi umur syarat mengadakan perkawinan, wajib memohon dispensasi kawin di Pengadilan Agama. Permohonan tersebut kemudian akan diputus oleh Majelis Hakim. Dalam proses penentuan izin dispensasi kawin, hakim mempunyai kekuasaan penuh untuk mengkontruksikan hukum terhadap latar belakang permohonan beserta menginterpretasi hukum, melakukan penafsiran hukum, serta menentukan regulasi yang paling pas untuk diterapkan terkait dengan perkara dispensasi perkawinan.

Faktor-faktor permohonan dispensasi kawin tersebutlah dengan mewancarai ketua Pengadilan Bapak Muslich sebagai berikut:

"Dispensasi kawin ini termasuk perkara voluntair, maksimal 2 bulan harus sudah putus. Beragam alasan yang diajukan oleh pemohon kepada pihak Pengadilan Agama mulai karena alasan; telah melakukan nikah sirri, khawatir timbul fitnah, sudah hamil, faktor ekonomi dan juga faktor pendidikan."15

Berdasarkan penjelasan Ketua Pengadilan Agama Pasuruan di atas dapat diketahui bahwa faktor yang melatarbelakangi permohonan dispensasi kawin ada 5 (lima) yaitu:

1) Telah Melakukan Pernikahan Sirri

Berdasarkan hasil wawancara dengan bapak Solihan bahwa kultur masyarakat di Pasuruan masih terlalu kukuh memandang fikih 
itu sebagai dokma yang tidak bisa di ubah lagi. Masyarakat di Pasuruan masih memegang fikih yang lama, yaitu fikih klasik. Beberapa masyarakat Pasuruan juga memandang bahwa ketika perempuan dan laki- laki berjalan berdua atau bukan muhrimnya, hal ini di pandang akan menimbulkan aib besar, sehingga para pihak orangtua menghindari ini dengan menikahkan sirri mereka. Para orangtua tidak memandang kematangan ataupun kesiapan anak-anak mereka dalam menciptakan suatukeluarga yang sakinah, mawaddah, warohmah. Yaitu dengan menganut bahwa dalam Islam pun tidak ada syarat yang ingin menikah. Bagi anak yang usianya masih kurang, para orangtua akan memilih untuk menikahkan anaknya dengan pernikahan sirri dahulu karena dianggap lebih cepat dan lebih mudah daripada harus menikahkan secara sah tetapi melaksanakan sidang terlebih dahulu.

Berdasarkan kutipan diatas bahwa masyarakat di Pasuruan tidak memandang bahwa fikih juga akan berkembang dengan fikih modern, hal ini patut untuk di perhatikan, dikarenakan zaman pun juga berkembang, untuk menyesuaikan dengan keadaan sekitar dan lingkungan. Menikahkan lah salah satu jalan pada masyarakat di Pasuruan, nikah sirri yang dilakukan untuk solusi yang mana mempermudah pernikahan tersebut, mencegah ditinggalkan salah satu pihak, kemudian menikahkan secara sahberdasarkan hukum.

2) Khawatir Timbulnya Fitnah

Alasan permohonan dispensasi nikah di Pasuruan selanjutnya disebabkan karena kekhawatiran timbulnya fitnah. Orang tua merasa khawatir terhadap anaknya yang sudah pacaran cukup lama dan sering kumpul bersama akan terjadi hal-hal yang tidak diinginkan. Sebagian besar mereka ini berada diwilayah pedesaan dan Pesisir. Tradisi di wilayah tersebut jika sepasang anak berlainan jenis sudah dewasa sering kumpul, menjadilah fitnah dan gunjingan tetangga, jadi orang tua khawatir sehingga diselesaikan dengan memutuskan menikahkan anaknya.

3) Hamil di Luar Nikah

Pergaulan bebas dan pengaruh media sosial untuk mengakses pornografi semakin mudah, sehingga mempengaruhi terjadinya hamil di luar nikah. Alasan ini sangat dominan sebagai alasan permohonan dispensasi kawin di Pengadilan Agama Pasuruan. Dispensasi kawin dijadikan jembatan menutup aib keluarga dan mencegah masalah baru lebih berbahaya jika tidak dinikahkan untuk para anak yang usianya masih dibawah 19 tahun. Pengakuan hamil di luar nikah sebagai alasan mengurusdispensasi nikah dinyatakan oleh Bahrul Ulum 
bin Kumaedi umur 17 tahun lebih 7 bulan dengan perempuan Zaziroh binti Kaeroni umur 16 tahun. Pengakuan tersebut disampaikan sebagaimana dalam hasil wawancara sebagai berikut;

"Sebenarnya saya tidak ingin terjadi seperti ini, apa boleh buat saya sudah hamil 4 bulan, sementara saya masih usia 16 tahun. Oleh KUA saya ditolak dengan alasan kurang umur, jadi harus ngurus dispensasi kawin ke Pengadilan Agama terlebih dahulu, saran KUA saya turuti, setelah mendapat surat dispensasi saya melangsungkan pernikahan diKUA setempat."

4) Faktor Ekonomi

Berdasarkan hasil wawancara dengan bapak Solihan, faktor selanjutnya dalam pengajuan dispensasi kawin adalah faktor ekonomi, dimana ada sebuah alasan yang dilontarkan oleh pihak pemohon kepada majelis hakim bahwa alasan mereka mengajukan permohonan ini untuk melangsungkan pernikahan yang disebabkan oleh paksaan untuk melunasi hutang orang tuanya. Ada sepasang orang tua yang memiliki hutang kepada seseorang rentenir di sebuah desa, lalu karena orang tuanya belum bisa melunasi hutangnya, sang rentenir memaksa anak perempuannya untuk menikah dengannya dengan alasan melunasi hutang serta bunga yang diberikan kepada orang tuanya tersebut.

Berdasarkan kutipan diatas dengan melunasi hutang orangtuanya, terpaksalah menikahkan anak mereka dengan secara paksa, hal ini juga salah satu sebab pengajuan dispensasi kawin di Pengadilan Agama Pasuruan.

5) Faktor Pendidikan

Berdasarkan hasil wawancara dengan bapak Muslich, di daerah Pesisir dan daerah desa di pegunungan terdapat sebuah kampung yang memang tingkat pendidikannya cukup rendah. Banyaknya para anak perempuan yang telah lulus SD/SMP akan dinikahkan dengan laki-laki baik yang dewasa atau masih seusia mereka dengan alasan sebuah kebudayaan atau agar dapat membantu ekonomi keluarga atau juga agar mengurangi beban biaya yang dikeluarkan oleh orang tua mereka.

Berdasarkan kutipan diatas bahwa rendahnya pendidikan bukandikarenakan ketidak inginan para pihak menolak sekolah, namun untuk membantu orangtua, terbantunya orangtua akan di utamakan pada masyarakat Pasuruan, karena letak dan lokasi pegunungan tidak seperti di kota. Hal ini juga alasan pemohon mengajukan dispensasi kawin di Pengadilan Agama Pasuruan. 


\section{Implikasi Hukum Perubahan Batasan Usia Perkawinan Karena PermohonanDispensasi Kawin Terhadap Peningkatan Angka Perceraian Di Pengadilan Agama Kabupaten Pasuruan}

Perceraian akibat pernikahan di bawah umur seakan menjadi hal yang lazim di Kota maupun Kabupaten Pasuruan. Kondisi tersebut mengacu sejumlah perkara yang ditemukan peneliti di Pengadilan Agama Pasuruan. Mengacu pada kondisi sebagaimana dimaksud, peneliti memusatkan pengkajian dengan memanfaatkan putusan yang ditemukan beserta bermacam konsiderasi hakim terkait dengan tema penelitian. Terdapat ribuan perkara perceraian dalam setiap tahun yang terjadi di Pengadilan Agama Pasuruan.

\section{Dampak Pasal 7 Undang-Undang Nomor 16 Tahun 2019 Terhadap Peningkatan Angka Perceraian di Pengadilan Agama Pasuruan}

1. Dampak Dispensasi Kawin Terhadap Pasal 7 Undang-Undang Nomor 16Tahun 2019 di Pengadilan Agama Pasuruan

Bahwa setiap yang ingin mengajukan dipensai kawin melalui Pengadilan Agama, dimana calon kedua belah pihak memenuhi syarat-syarat yang sudah di tentukan oleh Pengadilan Agama. Terkabulnya atau tertolaknya sebuah permohonan dispensasi kawin tergantung kepada Hakim dalam keputusannya. Dampak yang terjadi setelah dikabulkan atau ditolaknya, terbagi menjadi positif atau negatif. Bahwa Undang-Undang Nomor 16 Tahun 2019 sudah menetapkan batas umur paling rendah untuk menikah bagi perempuan dan laki-laki ialah 19 tahun. Peneliti memandang adanya dampak pertambahan dispensasi kawin diPengadilan Agama yang sangat tajam. Untuk menjaga kemashlahatan masyarakat, yang dimana peningkatan ini termasuk atau dikatagorikan kedalam hal yang buruk bagi pemerintah, dan baik bagi pemohon.

Menurut Muslich Dampak Undang-Undang Nomor 16 Pasal 7 Tahun 2019 terhadap dispensasi kawin di Pengadilan Agama Pasuruan dengan hasil wawancara sebagai berikut:

“Dampak nyata dari berlakunya Undang-Undang Nomor 16 Tahun 2019 tentang Perubahan Undang-Undang Nomor 1 Tahun 1974 adalah banjirnya permohonan atau perkara dispensasi kawin di Pengadilan Agama Pasuruan. Untuk menghindari penumpukan perkara dispensasi kawin ini saya harus kerja keras menata dan menjadwal sidang ini dengan perkara lain. Misalnya tentang perkara perceraian, waris dan perkara lainnya. Jam sidang dan majelis sidang juga ditambah, mengingat adanya batasan waktu penyelesaian perkara dispensasi kawin ini."

Dari hasil wawancara tersebut bahwa dampak Undang-Undang Nomor 16 Pasal 7 Tahun 2019 menghasilkan peningkatan yang sangat tajam di 
Pengadilan Agama Pasuruan, sehingga hakim pun tidak mempunyai waktu istirahat yang banyak, dikarenakan banyaknya kasus/perkara yang lain juga harus diselesaikan di hari itu. Kemudian dari dampak tersebut terjadilah beberapa alasan yang mengajukan dispensasi kawin, seperti hamil diluar nikah, nikah sirri, khawatirnya timbul fitnah, faktor ekonomi, faktor pendidikan, dari alasan-alasan tersebutlah menjadi dampak dispensasi kawin.

Kemudian dampak tidak hanya dispensasi kawin. Dari hasil wawancara diatas dapat dihasilkan, bahwa Muslich juga mendapatkan kesulitan yang bertumpukknya perkara-perkara di Pengadilan Agama Pasuruan, karena jadwal sidang pun sangat padat, sehingga 1 kasus pun mengambil waktunya sendiri. Karena perkara-perkara nya tidak hanya tentang pengajuan dispensasi kawin, juga ada berbagai perkara, seperti, perceraian, waris, hibah, dan lain-lainnya.

"Dispensasi kawin ini termasuk perkara voluntair, maksimal 2 bulan harus sudah putus. Beragam alasan yang diajukan oleh pemohon kepada pihak Pengadilan Agama mulai karena alasan; telah melakukan nikah sirri, khawatir timbul fitnah, sudah hamil, faktor ekonomi dan juga faktor pendidikan."

Dari hasil wawancara selanjutnya ini, kepada Bapak Muslich, bahwa inilah alasan yang menguatkan dampak Undang-Undang terhadap dispensasi kawin yang berada di Pengadilan Agama Pasuruan. Kemudian wawancara kepada Bapak Muslich yang berkaitan terkabulnya sebuah permohonan di Pengadilan AgamaPasuruan sebagai berikut:

"Dalam persoalan pertimbangan umur pasangan yang berperkara dibawah 16 tahun dikarenakan telah hamil diluar pernikahan, maka alasan ini akan berdampak buruk pada anak yang dilahirkan dari pasangan yang belum matang mental dan fisiknya. Tetapi jika majelis hakim tidak mengabulkan, akan menimbulkan aib keluarga di masyarakatnya. Karena hal semacam inilah alasan revisi pasal 7 undang-undang nomor 1 tahun 1974 menjadi landasan moral majelis hakim dalam memutuskan perkara dispensasi kawin."

Dari wawancara diatas bahwa setiap kebijakan hakim Pengadilan Agama Pasuruan tentang terkabulnya dispensasi kawin kepada calon laki-laki maupun perempuan yaitu bertujuan dengan kemaslahan, juga untuk terhadap syariat Islam (Maqasid Syariah) seperti memelihara keamanan anak (hifdzu an-nasl) menjaga kejiwaan anak yang memohon dispensasi kawin (hifzhu alnafs), serta kelanjutan pendidikannya (hifzhu al-aqli).

Pada wawancara diatas dapat dianalisis dalam Hukum Islam, hukum Islam dimana yang wajib menjaga seluruh aspek dalam kehidupan manusia yaitu adalah Maqasid Syariah. Pertama: (Hifdzu an-nasl) yaitu adalah menjaga keselamatan keturunan, terkabulnya sebuah dispensasi kawin juga berkaitan dengan terjaganya keturuan yang sah. Para Hakim pun setiap keputusan 
mempertimbangkannya dengan musyawarah dan memutuskan secara kemaslahatan untuk kedua pasangan, sehingga dapat menjalankan hubungan dengan sakinah mawaddah warohmah. Bergantungnya dengan dampak peningkatan memang memperberat kepada Pengadilan Agama dengan meningkatnya secara tajam, akan tetapi Pengadilan Agama juga menjadi dan berperan sebagai jembatan bagi masyarakat. Kedua, (Hifdzu an-nasf) hal ini berkaitan dengan sebelumnya dimana jiwa manusia sangat penting untuk dijaga, permohonan sebuah dispensasi kawin tidak hanya dengan alasanalasan yang lemah, akan tetapi yang sudah bisa diterima oleh hakim untuk dikabulkannya dispensasi tersebut, andai kata jika alasan yang diajukan dari pemohon, namun tertolaknya alasan tersebut karena Hakim melihat faktor usia mereka, namun pemohon tersebut sudah hamil, hal ini akan menjadi kerusakan sebuah rumah tangga, yang akan juga terjadinya merusak jiwa kepada dua calon, sehingga sangat penting untuk dijaga. Ketiga: (Hifd al-aqli) menjaga akal, keterkaitannya dengan peningkatan dispensasi kawin yaitu sebuah pendidikanjuga penting bagi kedua calon, sebab untuk kedepan tidak ada kesusahan dari berbagai masalah, mental mauapun fisik untuk menghadapi rumah tangga tidak bisa diremehkan, banyak terjadi cerai pun juga hanya karena rendah pendidikan, yang mana tidak luas untuk berfikir lebih mateng dan dewasa, pendidikan pun tidak hanya ilmu yang didapatkan, akan tetapi juga cara berfikir dengan berkomunikasi berbagai jenis orang mau dari yang dewasa hingga lansia yang lebih berpengalaman.

\section{Dampak Dispensasi Kawin Terhadap Peningkatan Angka Perceraian di Pengadilan Agama Pasuruan}

Menurut Bapak Solihan dampak terhadap peningkatan angka perceraian

di Pangadilan Agama Pasuruan, keterkaitannya kepada peningkatan dispensasi kawin yang sebelumnya peneliti analisis, sehingga juga meningkat angka perceraian di PA Pasuruan terjadi selama kurang waktu 2015-2021 (Jan-Feb) yaitu 12.045 kasus perceraian. Jumlah perceraian tersebut merupakan jumlah data dari cerai gugat beserta cerai talak yang diproses di Pengadilan Agama Pasuruan. Adapun contoh pada keterkaitan dispensasi kawin kemudian cerai sebagai berikut dengan hasil wawancara bepada Bapak Imamuddin:

Contoh dari pemohon gugatan perceraian yang dulunya mengajukan permohonan dispensasi kawin, pemohon dari daerah Kecamatan Lumbang dengancatin perempuan usia 16 tahun lebih 7 bulan dengan catin laki-laki 19 Tahun. Dia mengajukan dispensasi karena kurang umur, sedangkan mereka harus segera melakukan pernikahan dikarena pihak perempuan sudah mengandung 2 bulan. Setelah umur perkawinan 10 bulan, mereka 
mengajukan permohonan cerai gugat dengan alasan KDRT.

Pada asasnya, perceraian ialah salah satu dari peristiwa hukum yang memunculkan atau mengurangi kewajiban maupun hak seseorang. ada beberapa alasan dampak dari terjadinya peningkatan perceraian di Pengadilan Agama Pasuruan sebagai berikut:

1. Meninggalkan salah satu pihak

2. Kekerasan Dalam Rumah Tangga

3. Perselisihan dan Pertengkaran Terus Menerus

4. Ekonomi

Kemudian wawancara kepada Bapak Muslich mengemukakan jika bahwa mereka yang memohon dispensasi didasari sejumlah latar belakang, seperti ingin menikah karena keduanya telah saling mencintai dan sudah tidak bisa dipisahkan lagi. Namun, setelah dikabulkan, selang beberapa tahun bahkan beberapa bulan kemudian ada yang mengurus perceraian dengan latar belakang paksaan dari orang tua di awal menikah yang mengakibatkan tidak adanya rasa saling mencintai Selama berumah tangga. Hal tersebut menandakan terdapat penyimpangan dengan apa yang disampaikan saat memohon dispensasi perkawinan di masa lalu. Alasan-alasan tersebut sebagai berikut:

1. Suami tidak bertanggung jawab, baik lahir maupun batin isteri, terutama dalam kebutuhan ekonomi.

2. Suami atau isteri mudah tersinggung.

3. Keterpaksaan karena perkawinan paksa.

4. Kepribadian anak yang masih labil.

5. Faktor pendiddikan.

6. Faktor kemajuan teknologi.

7.

Teori Efektivitas Hukum Terhadap Undang-undang Nomor 16 Pasal 7 Tahun 2019

Pada teori efektivitas hukum peneliti memandang bahwa undangundang Nomor 16 pasal 7 Tahun 2019 ini efektif, namun untuk kesadaran masyarakat masih belum efektif, Undang-Undang ini pun sudah jelas berbunyi "Perkawinan hanya diizinkan apabila pria dan wanita sudah mencapai umur 19 tahun". Penelitian dengan melakukan wawancara yang berlokasi di Pengadilan Agama Pasuruan, dengan hasil mendapatkan data-data melalui dokumentasi hingga merekamnya dan mengamatinya, salah satu faktor yang melatarbelakanginya sehingga belum mewujudkan kesadaran masyarakat adalah rendahnya pendidikan yang menyebabkan pernikahan dini serta hamil diluar nikah. Juga masyrakat disana berpegang teguh kepada panutan Agama klasik hingga menolak atau tidak menerima dengan alasan kita sudah begini 
saja dengan fikih klasik. Pada umumnya sebagai masyarakat harus menyadari bahwa pernikahan dini pun tidak baik bagi para calon jika belum ada persiapan dan kematangan dalam berumah tangga. Dalam hukum efektif harus memiliki dua faktor, yaitu faktor internal dan faktor eksternal. Hukum pada kasus ini termasuk katagori tidak efektif dikarenakan banyaknya masyarakat yang sulit untuk dikontrol satu-persatu, sehingga menyebabkan banyak masyarakat mengajukan dispensasi kawin di Pengadilan Agama Pasuruan, tujuan dari Undang-Undang tersebut adalah untuk mengurangi permohonan dispensasi kawin dan pernikahan dini. Akan tetapi faktanya yang terjadin di lapangan merupakan keterbalikan dari tujuan dibuatnya UndangUndang tersebut, sehingga menyebabkan semakin bertambahnya permohonan dispensasi kawin dari tahun ke tahun. Efektifnya UndangUndang tersebut yaitu adanya ketidakmungkinan penolakan permohonan dispensasi kawin dengan alasan hamil dahulu. Dalam hal ini Hakim tidak bisa menolak, karena akan berdampak buruk bagi calom istri dan dirinya sendiri serta keluarganya dalam lingkungan masyarakat.

\section{Dampak Positif Pasal 7 Undang-Undang Nomor 16 Tahun 2019 Terhadap Permohonan Dispensasi Kawin Di Pengadilan Agama Pasuruan}

Pada putusan hakim dalam mengabulkan permintaan pemohon terhadapdispensasi kawin yang berdampak positif sebagai berikut:

a. Memperjelas status perkawinan;

b. Memperkuat kekuatan hukum nasab seorang anak kepadaayahnya;

c. Adanya penerimaan yang positif dari masyarakat;

d. Terhindar dari persepsi buruk serta cemoohan masyarakat;

e. Menyelamatkan diri sendiri dari aktivitas perzinaan.

\section{Dampak Negatif Pasal 7 Undang-Undang Nomor 16 Tahun 2019 Terhadap Permohonan Dispensasi Kawin Di Pengadilan Agama Pasuruan}

Berdasarkan hasil wawancara dengan Bapak Muslich, pada putusan hakim dalam mengabulkan permintaan pemohon terhadap dispensasi kawin yang berdampak negatifsebagai berikut:

a. Kemungkinan terjadinya perceraian pada pasangan yang nikah di bawah umur semakin tinggi;

b. Kemungkinan terjadinya kematian karena kehamilan di bawah umur tinggi;

c. Tingginya kemungkinan terjadinya kanker serviks pada ibu yang terlalu muda akibat dari aktivitas seks secara bebas maupun berhubungan dengan pasangan yang berbeda-beda; 
d. Tradisi dan budaya seringkali digunakan sebagai alasan bagi pelaksanaan perkawinan di bawah umur.

\section{KESIMPULAN}

Pembaharuan Pasal 7 Undang-Undang Nomor 16 Tahun 2019 terhadap Undang-Undang Nomor 1 Tahun 1974 mempunyai dampak besar bagi kenaikan jumlah pengajuan dispensasi kawin di Pengadilan Agama Pasuruan. Hasil penelitian mengemukakan jika tingkat perceraian di Pengadilan Agama Pasuruan terus meningkat dari tahun 2015-2021 (Januari-Februari). Faktor yang melatarbelakangi meningkatnya jumlah perceraian di Pengadilan Pasuruan, antara lain meninggalkan salah satu pihak, kekerasan dalam rumah tangga, perselisihan dan pertengkaran terus menerus, dan ekonomi. Di setiap tahunnya, pasangan yang mengajukan perceraian selalu ada dari pasangan yang dahulunya mengajukan dispensasi nikah, kecuali di tahun 2021 (JanuariFebruari) untuk pasangan yang mengajukan perceraian belum ada yang pasangan dahulunya mengajukanpermohonan dispensasi nikah.

Solusi Untuk masyarakat, direkomendasikan agar senantiasa meningkatkan kesadaran hukum serta mengikuti peraturan serta hukum yang berlaku di Negara, bahwa usia minimal laki-laki atau perempuan yang akan melangsungkan nikah adalah 19 Tahun. Dan para orang tua juga harus lebih memperhatikan anak-anaknya agar tidak terpengaruhi oleh bebasnya pergaulan pada zaman ini.

\section{DAFTAR PUSTAKA}

Ad-Dimasyqi Ismail Ibnu Kasir. (2000). Tafsir Ibnu Kasir, terj. Bahrun Abu Bakar dkk. Bandung: Sinar Baru Algensido,

Ahmad bin Muhammad bin Hanbal bin Hilal bin Asad Al-Syaibani. Musnad AlImam Ahmad bin Hanbal. 11/227. Maktabah Syamilah. https://almaktaba.org/book/13157/6511.

Al-khatib Yahya Abdurrahman. (2003). Hukum-hukum Wanita Hamil (Ibadah, Perdata,Pidana). Jatim: Al-Izzah.

Al-Hamdani. (2002). Hukum Perkawinan Islam. Jakarta: Pustaka Amani.

Amirudin, Zainal Asikin. (2010). Pengantar Metode penelitian Hukum. Jakarta:Rajawali Pers.

Armia. (2018). Fikih Munakahat. Medan: Manhaji. 
Arto Mukti. (2007). Praktek Perkara Perdata di Pengadilan Agama. Yogyakarta: Pustaka Pelajar.

Ball John. (1982). Indonesia Legal History (1602-1848). Sydney: Oughtershaw Press.

Bungin, Burhan. (2013). Metodologi Penelitian Sosial dan Ekonomi. Jakarta: Kencana.

Bisri Cik Hasan. (2003). Peradilan Agama di Indonesia. Jakarta: PT. Raja Grafindo Persada.

Mahardika, Muhammad, Panji. (2018). Analisis Yuridis Terhadap kemaslahatan Dalam Pertimbangan Hukum Penetapan Ijin Dispensasi Nikah di Pengadilan Agama Kabupaten Malang. Skripsi. Surabaya: UIN Sunan Ampel.

Marzuki, Peter Mahmud. (2007). Penelitian Hukum. jakarta: Kencana.

Masyuri, Zainuddin. (2009). Metode Pendekatan Praktis dan Aplikatif. Bandung: PR.Refika Aditama.

Savendra, Anggi, Dian. (2019) Pengaruh Pernikahan di Bawah Umur Terhadap Keharmonisan Rumah Tangga (Studi Kasus di Desa Banarjoyo Kecamatan Batanghari Kabupaten Lampung Timur). Skripsi. Lampung: IAIN Metro.

Rosyid Roihan. (2007). Hukum Acara Peradilan Agama. Jakarta: PT. Raja GrafindoPersada.

Subekti, R. R. Tjitrosoedibio. (1996). Kamus Hukum. Jakarta: PT. Pradnya Paramitha,.

Summa Muhammad Amin. (2004). Hukum Keluarga Islam di Dunia Islam. Jakarta:Rajawali Press.

Sudarso. (1992). Nomor Kamus Hukum. Jakarta: Rineka Cipta.

Sitompul Anwar. (1984). Kewenangan dan Tata Cara Berperkara di Peradilan Agama. Bandung: Armico

Sabiq Sayyid. (1993). Fiqih Sunnah. Bandung: PT. Al-Maarif.

Syarifudin Amir. (2009). Hukum Perkawinan Islam di Indonesia. Jakarta: Kencana. 
Suyito Imam. (2011). Karya Tulis Ilmiah. Bandung: PT. Refika Aditma.

Sugiyoni. (2014). Metode Penelitian Kuantitatif kualitatif dan R\&D. Bandung:

Alfabeta.

Tasfiq, Mutsla, Sofyan. (2018). Dispensasi Kawin Pada Pasal 7 Undang-undang Nomor 1 Tahun 1974 yang Dimanfaatkan Untuk Kawin Sebab Hamil (Studi Pandangan Hakim di Pengadilan Agama Kabupaten dan Kota MalangPerspektif efektivitas Hukum). Tesis. Malang: UIN Malang. 